African J. Biol. Sci., 17 (1): 1-14 (2021)

ISSN 1687-4870

www.ajbs.journals.ekb.eg

e- ISSN 2314-5501 (online)

E.mail: aasdjournal@yahoo.com

\title{
Potential ameliorative effects of Ocimum basilicum extract and leaves on testicular toxicity induced by sodium arsenite in male rats
}

\author{
Lamiaa M. Abd EL-Maoula* \\ Nutrition and Food Science Department, Faculty of Home Economics, Al- Azhar University, \\ Tanta, Egypt \\ * dr_lamiaamostafa@azhar.edu.eg
}

Received: January 2, 2021; Accepted: Jan. 30, 2021; Available online: Feb. 2, 2021

\begin{abstract}
Arsenite is a major environmental chemical and a known reproductive toxicant that induced the depression of spermatogenesis and androgenesis in males. Arsenic commonly contaminates the environment via insecticides and pesticides and seepage through drinking water. The present study was designed to investigate the effect of ethanolic Ocimum basilicum extract and leaves against testicular toxicity induced by sodium arsenite in male rats. Thirty male albino rats were divided into two main groups: The first main group (5 rats) was kept as (G-) a negative control group. The second main group (25 rats) was injected $\mathrm{NaAsO}_{2}(4 \mathrm{mg} / \mathrm{kg}$ body weight) in $0.9 \% \mathrm{NaCl}$ interaperitoneally only twice. After that, the rats were divided into five subgroups as following: subgroup (1): kept as (G+) a positive group. Subgroups ( $2 \& 3$ ) were given ethanolic Ocimum basilicum extract ( 250 and $500 \mathrm{mg} / \mathrm{kg}$ bodyweight) and Subgroups ( $4 \& 5$ ) were given powder leaves of Ocimum (equivalent doses) added to the diet for ( 28 days). At the end of the experiment, rats were sacrificed and biological evaluations were calculated. The weights of the reproductive organs were recorded. Sperm count, motility, progressive motility and normal form were evaluated. Serum sex hormone (luteinizing hormone, $\mathrm{LH}$ ), follicle stimulating hormone (FSH) and testosterone were analyzed. Antioxidant enzymes were assayed in testicular tissue. Results showed that treatment groups were associated with significant increase in sperm parameters, serum sex hormone, $\mathrm{GP}_{\mathrm{X}}, \mathrm{SOD}$ and CAT. In contrast level of MDA were significantly $(\mathrm{p} \leq 0.05)$ decreased as compared with the positive control group. In Conclusions: ethanolic Ocimum basilicum extract and leaves have a potent effect in the treatment of testicular toxicity caused by sodium arsenite. This effect may be due to the presence of flavonoides and antioxidant properties of Ocimum basilicum which may be useful in the treatment of testicular toxicity caused by arsenite.
\end{abstract}

Keywords: Testicular toxicity, sodium arsenite, Ocimum basilicum, Antioxidant enzymes, Sperm parameters, LH, FSH, testosterone.

\section{INTRODUCTION}

Arsenical compounds are environmental contaminant with manifold effects in animal and human populations. Human are exposed to arsenic mainly through water, food and drugs as well as in the form of herbicides, insecticides, rodenticides and food preservatives (Mehranjani and Hemadi, 2007). Though adverse, on the other hand, reality relics that a large number of populations in some areas of the world are drinking arsenic- contaminated ground water and the number of cases torment from As-induced organ dysfunctions are increasing terrifically (Das et al., 2009).

Epidemiologic studies have documented that exposure to arsenic is linked with male reproductive toxicity (Da Silva et al., 2017; Zubair et al., 2017). Ommati et al. (2019) reported the link between arsenic and male infertility. Reproductive health is a condition of complete mental, physical, and social 
Lamiaa M. Abd EL-Maoula

wellness, as referred by World Health Organization. It becomes a vital feature of general health and human development. If it is not maintained at present, it can affect the health of the next generation (Preethi et al., 2020). Studies have shown that arsenic intoxication results in testicular regression in mice (Mamoun et al., 2018). Testicular degeneration and tissue necrosis in mice due to exposure of arsenic have been reported (Guvvala et al., 2016). A decrease in sperm count and motility has been demonstrated in a dose-dependent manner after arsenic treatment (Zhang et al., 2011).

The use of medicinal plants in folk medicine is an age-long practice in various parts of the globe for both preventive and curative purposes. Today, it is estimated that about $80 \%$ of the world population relies on botanical preparations as medicine to meet their healthcare needs (Ogbera et al., 2010). Ocimum basilicum L. (sweet basil) a member of Lamiaceae family is native throughout the old World and cultivated for religious and medicinal purposes. Basil was originated in Asia and Africa. Basil is popular for its culinary and ornamental uses. Various parts of this plant have been widely used in traditional medicine. The leaves and flowers of basil are used in folk medicine as a tonic and vermifuge. Studies showed that basil possesses central nervous system (CNS) depressant, anticancer, cardiac stimulant, hepatoprotective, hypoglycemic, hypolipidemic, immunomodulator, analgesic, anti-inflammatory, antimicrobial, antioxidant, antiulcerogenic, chemomodulatory and larvicidal activities (Ahmed et al., 2015).

Many studies have reported that basil leaf extracts have potent antioxidant, antiaging, anticancer, antiviral, and antimicrobial properties (Manosroi et al., 2006). Sethi et al. (2003) reported that the leaves of basil possess good antioxidant and antistress potentials in experimental animals.
Consumption of basil or basil oil has been associated with a reduction in total cholesterol, low-density lipoprotein and triglyceride levels (Harnafi et al., 2009). Supplementation with $O$. sanctum leaf extract reduced the severity of hydropericardium, hepatitis, myocarditis accompanied with hemorrhages, lung edema, lymphocytic depletion in lymphoid organs and focal interstitial nephritis (Batra and Gupta, 2006).

The present study aims to investigate the possible beneficial effects of Ocimum basilicum as a source of natural antioxidants to aid the sperm parameters in rats against testicular alterations in male albino rats.

\section{Materials:}

MATERIAL AND METHODS

1- Ocimum basilicum was purchased from local market, 6th October City, Egypt.

2- Sodium arsenite $\left(\mathrm{NaAsO}_{2}\right)$ : was purchased from Al-Rahma Company in Zigzag in the form of powder.

3- Casein ( $85 \%$ protein), choline chloride, DL-methionine, vitamins and salt mixture were obtained from El-Sharqiya Co., Sun flower oil and corn starch also were obtained from local market, Tanta, Egypt. 95\% ethanol was purchase from Al-Rahma Company in Zagazig in liquid form.

4- Thirty normal male albino rats of "Sprague Dawley" Strain weighing (200 \pm $10 \mathrm{~g})$ were obtained from the laboratory animal colony, Ministry of Health and Population, Helwan, Cairo, Egypt.

\section{Methods:}

\section{Preparation of leaves:}

Ocimum basilicum leaves were picked fresh then cleaned. Leaves were dried by dry air at room temperature then grinded using a blinder into fine powder and were kept separately in dark glass containers in a refrigerator till use

\section{Preparation of leaves extract:}

$800 \mathrm{~g}$ of shade dried leaves powder were immersed in $4 \mathrm{~L}$ of $95 \%$ ethanol and 


\section{Potential ameliorative effects of Ocimum basilicum extract and leaves on testicular toxicity induced by sodium arsenite in male rats}

left for $24 \mathrm{~h}$ with stirring and then filtered. This was repeated twice with $2 \mathrm{~L}$ of $95 \%$ ethanol. Thus, a total of $6.5 \mathrm{~L}$ filtrate was collected and concentrated by rotary vapor at $40^{\circ} \mathrm{C}$. The yield of ethanol extract (EE) was $42 \mathrm{~g}(5.25 \%)$. The extraction of the selected plants was done by the method of (Villasenor et al., 2002).

\section{Chemical analysis:}

Leaves of $O$. basilicum were subjected to chemical analysis in order to determine: Total phenolic: Phenolic compounds in dried leaves were determined by HPLC according to the method of Goupy et al. (1999) at Central Lab of Food Technology Research Institute Agric. Res. Cent. Egypt.

\section{Experimental design:}

Thirty healthy adult male albino rats "Sprague Dawley strain" weighing (200 \pm $10 \mathrm{~g})$ were kept in single wire cages with wire bottoms under hygienic conditions. Rats were divided into two main groups:

The first main group (5 rats) was fed on basal diet and administrated distilled water orally for 28 days and kept as a negative control group (G-).

The second main group (25 rats) was interaperitoneally injected by sodium arsenite $\left(\mathrm{NaAsO}_{2}\right)(4 \mathrm{mg} / \mathrm{kg}$ body weight $)$ in $0.9 \% \mathrm{NaCl}$ twice only for two consecutive days (Sharma et al., 2007).After that, the rats were divided into five subgroups as following:

Subgroup (1): was fed on basal diet as a positive control group $(\mathrm{G}+)$.

Subgroup (2): was fed on basal diet $+(250$ $\mathrm{mg} / \mathrm{kg}$ body weight) $O$. basilicum extract was administered orally.

Subgroup (3): was fed on basal diet $+(500$ $\mathrm{mg} / \mathrm{kg}$ body weight) $O$. basilicum extract was administered orally.

Subgroup (4): was fed on basal diet + amount of $O$. basilicum powder which equalize extract $250 \mathrm{mg}$ / body weight.
Subgroup (5): was fed on basal diet + amount of $O$. basilicum powder which equalize extract $500 \mathrm{mg} / \mathrm{kg}$ body weight.

At the end of the experiment the rats were fasted overnight before sacrificed and the blood samples were collected from each rat and centrifuged to obtain the serum. The testis and prostate were collected and removed, cleaned in saline solution, dried by filter paper and weighted.

\section{Biological parameters evaluation:}

During the experiment (28 days), feed intake was recorded every day, and body weight was recorded every week. Biological evaluation of the different diets was carried out by determination of body weight gain \% (BWG \%) feed efficiency ratio (FER) according to Chapman et al. (1959).

Sperm parameters:

Sperm count, sperm motility, progressive motility and normal form were calculated according to the methods of Ekaluo et al. (2005) and Ekaluo et al. (2013).

\section{Biochemical analysis:}

Hormonal assays:

The levels of hormones were measured in serum according to the principle highlighted by (Tietz, 1995) for testosterone, while the method of Uotila et al. (1981) was used for luteinizing and follicle stimulating hormones.

\section{Antioxidant enzymes and}

Malondialdehyde in testes tissue:

Glutathione peroxidase (GPx), Catalase (CAT), Super Oxide Dismutase (SOD) and Malondialdehyde (MDA) were determined according to the methods of Paglia and Valentine, (1967), Ohkawa et al (1979), Nishikimi et al. (1972) and Aebi (1984), respecively.

Statistical analysis:

Statistical analysis was carried out using the programme of Statistical Package for the 


\section{Lamiaa M. Abd EL-Maoula}

Social Sciences (SPSS) and PC statistical software (Version 20; Untitled-SPSS Data Editor).The results were expressed as mean \pm Standard deviation (mean \pm S.D.). Data were analyzed using one way classification, analysis of variance (ANOVA) (Sendcor and Cochran, 1979).

\section{Chemical analysis:}

\section{RESULTS}

Phenolic compound of Ocimum basilicum leaves extract:

High-performance liquid chromategraphy (HPLC) analyses of sweet basil (Ocimum basilicum) leaves extract are reported in Figure (1). HPLC analysis revealed the presence of twenty one compounds in leaves extract. The data illustrated the highest amount of phenolic compounds in $O$. basilicum recorded for Catechein, Benzoic, P-OH-benzoic, Ellagic, Salycillic and Pyrogalloi. Meanwhile, Cinnamic and Alpha-coumaric were found to be the lowest amount of phenolic compounds.

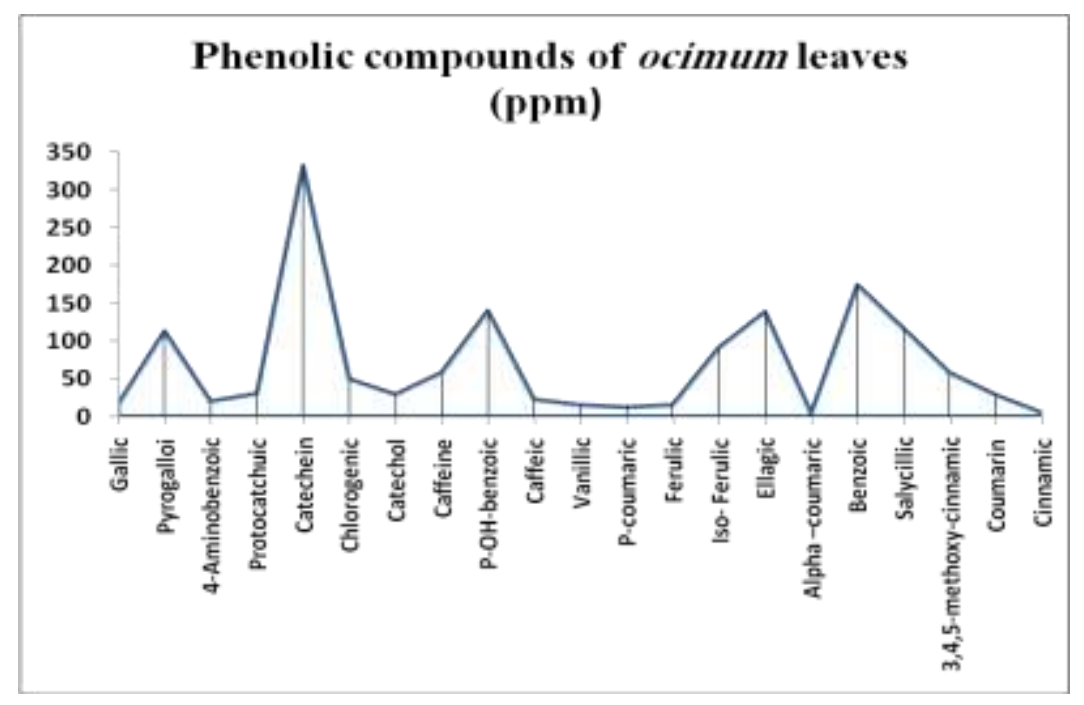

Fig (1): Phenolic compounds of Ocimum basilicum leaves extract (ppm) by HPLC analysis.

Effect of Ocimum basilicum extract and leaves on biological parameters in rats with induced testicular toxicity.

Data present in Table (1) showed the effect $O$. basilicum leaves powder and extract on feed intake, body weight gain and feed efficiency ratio. The results showed that there were a significant decrease in feed intake, body weight gain and feed efficiency ratio in sodium arsenite group (Control +ve) compared with negative group. All experimental groups treated with $O$. basilicum leaves powder and extract recorded significant increase in their FI, BWG\% and FER when compared to $(+\mathrm{ve})$ control group. The best results were recorded for the groups treated with Ocimum extract $(500 \mathrm{mg} / \mathrm{kg})$ as compared with negative control group. 


\section{Potential ameliorative effects of Ocimum basilicum extract and leaves on testicular toxicity} induced by sodium arsenite in male rats

Table (1): Effect of Ocimum basilicum extract and leaves on feed intake (FI), body weight gain\% $(B W G)$ and feed efficiency ratio (FER) in rats with induced testicular toxicity. (mean \pm SD)

\begin{tabular}{|c|c|c|c|}
\hline \multirow{2}{*}{ Groups } & \multicolumn{3}{|c|}{$\begin{array}{r}\text { Parameters } \\
\end{array}$} \\
\hline & FI (g/28days) & BWG (\%) & FER \\
\hline Control-ve & $293.33 \pm 3.06^{\mathrm{a}}$ & $32.92 \pm 1.24^{\mathrm{a}}$ & $0.11 \pm 0.004^{\mathrm{a}}$ \\
\hline Control +ve & $241.33 \pm 4.16^{\mathrm{d}}$ & $18.84 \pm 1.17^{\mathrm{d}}$ & $0.07 \pm 0.004^{\mathrm{e}}$ \\
\hline Ocimum extract $(250 \mathrm{mg} / \mathrm{kg})$ & $263.67 \pm 3.79^{\mathrm{c}}$ & $24.24 \pm 1.27^{\mathrm{c}}$ & $0.09 \pm 0.004^{\mathrm{cd}}$ \\
\hline Ocimum extract $(500 \mathrm{mg} / \mathrm{kg})$ & $278 \pm 6.56^{b}$ & $28.20 \pm 1.00^{\mathrm{b}}$ & $0.10 \pm 0.003^{\mathrm{bc}}$ \\
\hline Ocimum powder equalize extract $(250 \mathrm{mg} / \mathrm{kg})$ & $269.67 \pm 5.51^{\mathrm{bc}}$ & $24.29 \pm 1.41^{\mathrm{c}}$ & $0.09 \pm 0.004^{\mathrm{d}}$ \\
\hline Ocimum powder equalize extract $(500 \mathrm{mg} / \mathrm{kg})$ & $272 \pm 4.58^{\mathrm{bc}}$ & $27.30 \pm 1.39^{\mathrm{b}}$ & $0.10 \pm 0.005^{\mathrm{b}}$ \\
\hline
\end{tabular}

Data are presented as mean \pm SD. Values with different letters indicate significant differences among groups at $\mathrm{p} \leq 0.05$.

\section{Effect of Ocimum basilicum extract and} leaves on weight of prostate and testes in rats with induced testicular toxicity

The results in the Table (2) indicated that weight of prostate and testes recorded significant decrease in positive control group compared with negative one. All treated groups had significant increase in mean values of prostate weight and testes weight when compared with (+ve) control group $(0.34 \pm 0.04 \& 1.65 \pm 0.08$, respectively).

Table (2): Effect of Ocimum basilicum extract and leaves on weight of prostate and testes in rats with induced testicular toxicity.

\begin{tabular}{|c|c|c|}
\hline \multirow[b]{2}{*}{ Groups } & \multicolumn{2}{|c|}{ Parameters } \\
\hline & $\begin{array}{c}\text { Prostate weight } \\
\text { (g/100 g b.wt.) }\end{array}$ & $\begin{array}{l}\text { Testes weight } \\
(\mathrm{g} / 100 \mathrm{~g} \text { b.wt. })\end{array}$ \\
\hline Control-ve & $0.61 \pm 0.03^{\mathrm{a}}$ & $2.27 \pm 0.02^{\mathrm{a}}$ \\
\hline Control +ve & $0.34 \pm 0.04^{\mathrm{c}}$ & $1.65 \pm 0.08^{\mathrm{c}}$ \\
\hline Ocimum extract $(250 \mathrm{mg} / \mathrm{kg})$ & $0.58 \pm 0.02^{\mathrm{ab}}$ & $2.23 \pm 0.01^{\mathrm{ab}}$ \\
\hline Ocimum extract $(500 \mathrm{mg} / \mathrm{kg})$ & $0.63 \pm 0.03^{\mathrm{a}}$ & $2.26 \pm 0.01^{\mathrm{a}}$ \\
\hline Ocimum powder equalize extract $(250 \mathrm{mg} / \mathrm{kg})$ & $0.53 \pm 0.03^{b}$ & $2.16 \pm 0.02^{b}$ \\
\hline Ocimum powder equalize extract $(500 \mathrm{mg} / \mathrm{kg})$ & $0.54 \pm 0.03^{\mathrm{b}}$ & $2.19 \pm 0.01^{\mathrm{b}}$ \\
\hline
\end{tabular}

Data are presented as mean \pm SD. Values with different letters indicate significant differences among groups at $\mathrm{p} \leq 0.05$.

\section{Effect of Ocimum basilicum extract and leaves on sperm parameters in rats with induced testicular toxicity}

There was a significant reduction in sperm count, sperm motility, progressive motility and sperm normal form $(\mathrm{P}<0.05)$ after injection with sodium arsenite in comparison to the normal control group. Administrations of rats in subgroups (1-4) $O$. basilicum leaves powder and extract produced significant increase in their sperm count, sperm motility, progressive motility and normal form compared with positive group. The best results was recorded for the group treated with Ocimum extract $(500 \mathrm{mg} / \mathrm{kg})$, which recorded the nearest values of sperm parameters from those of normal control group (Table 3 ). 
Lamiaa M. Abd EL-Maoula

Table (3): Effect of Ocimum basilicum extract and leaves on sperm parameters in rats with induced testicular toxicity.

\begin{tabular}{|c|c|c|c|c|}
\hline \multirow[b]{2}{*}{ Groups } & \multicolumn{4}{|c|}{ Parameters } \\
\hline & $\begin{array}{c}\text { Sperm } \\
\text { count } \\
(\times 106 / \mathrm{ml})\end{array}$ & $\begin{array}{c}\text { Sperm } \\
\text { motility }(\%)\end{array}$ & $\begin{array}{c}\text { Progressive } \\
\text { motility } \\
(\%)\end{array}$ & $\begin{array}{c}\text { Normal } \\
\text { form } \\
(\%)\end{array}$ \\
\hline Control-ve & $65.52 \pm 2.01^{\mathrm{a}}$ & $75.33 \pm 3.51^{\mathrm{a}}$ & $61.00 \pm 2.65^{\mathrm{a}}$ & $71.00 \pm 2.65^{\mathrm{a}}$ \\
\hline Control +ve & $34.16 \pm 2.55^{\mathrm{d}}$ & $39.67 \pm 3.06^{\mathrm{e}}$ & $33.33 \pm 3.21^{\mathrm{e}}$ & $38.00 \pm 3.00^{\mathrm{c}}$ \\
\hline Ocimum extract $(250 \mathrm{mg} / \mathrm{kg})$ & $52.92 \pm 3.12^{\mathrm{c}}$ & $64.67 \pm 2.08^{\mathrm{bc}}$ & $50.33 \pm 1.53^{\mathrm{c}}$ & $62.67 \pm 2.52^{b}$ \\
\hline Ocimum extract $(500 \mathrm{mg} / \mathrm{kg})$ & $58.67 \pm 2.61^{\mathrm{b}}$ & $68.33 \pm 4.04^{\mathrm{b}}$ & $55.00 \pm 2.65^{b}$ & $67.00 \pm 2.65^{\mathrm{a}}$ \\
\hline Ocimum powder equalize extract $(250 \mathrm{mg} / \mathrm{kg})$ & $50.32 \pm 3.13^{\mathrm{c}}$ & $53.67 \pm 3.51^{\mathrm{d}}$ & $44.33 \pm 2.08^{\mathrm{d}}$ & $58.33 \pm 1.53^{\mathrm{b}}$ \\
\hline Ocimum powder equalize extract $(500 \mathrm{mg} / \mathrm{kg})$ & $53.10 \pm 3.10^{c}$ & $59.67 \pm 1.53^{\mathrm{c}}$ & $47.00 \pm 3.00^{\mathrm{cd}}$ & $61.33 \pm 1.53^{b}$ \\
\hline
\end{tabular}

Data are presented as mean \pm SD. Values with different letters indicate significant differences among groups at $\mathrm{p} \leq 0.05$.

Effect of Ocimum basilicum extract and leaves on testes hormone's (FSH, LH and testosterone) in rats with induced testicular toxicity

FSH, LH and testosterone levels in plasma of different investigated groups were illustrated in Table (4). In arsenic treated rats $($ Control $+v e)$ the levels of FSH, LH and testosterone were significantly $(\mathrm{P}<0.05)$ decreased when compared with the negative control group. The other treated groups showed significant increase in their FSH, LH and testosterone hormones compared with the positive control group. The best result in tests hormone's was shown in rats treated with Ocimum extract $(500 \mathrm{mg} / \mathrm{kg})$, which recorded the nearest values from those of the normal control group.

Table (4): Effect of Ocimum basilicum extract and leaves on testes hormone's in rats with induced testicular toxicity.

\begin{tabular}{|c|c|c|c|}
\hline \multirow[b]{2}{*}{ Groups } & \multicolumn{3}{|c|}{ Parameters } \\
\hline & $\begin{array}{l}\text { FSH } \\
(\mathrm{ng} / \mathrm{ml})\end{array}$ & $\begin{array}{l}\mathrm{LH} \\
(\mathrm{ng} / \mathrm{ml})\end{array}$ & $\begin{array}{l}\text { Testosterone } \\
\text { H. }(\mathrm{ng} / \mathrm{ml})\end{array}$ \\
\hline Control-ve & $1.36 \pm 0.03^{\mathrm{a}}$ & $1.87 \pm 0.08^{\mathrm{a}}$ & $3.61 \pm 0.03^{\mathrm{a}}$ \\
\hline Control +ve & $0.19 \pm 0.01^{\mathrm{f}}$ & $0.42 \pm 0.04^{\mathrm{e}}$ & $1.12 \pm 0.03^{\mathrm{f}}$ \\
\hline Ocimum extract $(250 \mathrm{mg} / \mathrm{kg})$ & $1.08 \pm 0.03^{\mathrm{c}}$ & $1.34 \pm 0.06^{\mathrm{c}}$ & $2.62 \pm 0.02^{\mathrm{d}}$ \\
\hline Ocimum extract $(500 \mathrm{mg} / \mathrm{kg})$ & $1.21 \pm 0.02^{\mathrm{b}}$ & $1.55 \pm 0.07^{\mathrm{b}}$ & $3.08 \pm 0.03^{b}$ \\
\hline Ocimum powder equalize extract $(250 \mathrm{mg} / \mathrm{kg})$ & $0.88 \pm 0.03^{\mathrm{e}}$ & $1.23 \pm 0.02^{\mathrm{d}}$ & $2.48 \pm 0.03^{\mathrm{e}}$ \\
\hline Ocimum powder equalize extract $(500 \mathrm{mg} / \mathrm{kg})$ & $1.01 \pm 0.02^{\mathrm{d}}$ & $1.35 \pm 0.05^{\mathrm{c}}$ & $2.73 \pm 0.03^{\mathrm{c}}$ \\
\hline
\end{tabular}

Data are presented as mean \pm SD. Values with different letters indicate significant differences among groups at $\mathrm{p} \leq 0.05$.

Effect of Ocimum basilicum extract and leaves on antioxidant enzymes (GPX, SOD and CAT) and malondialdehyde (MDA) in rats with induced testicular toxicity

Glutathione peroxidase (GPx), Superoxide dismutase (SOD) and catalase (CAT) were determined as important endogenous antioxidant enzymes in the testis tissue of the investigated rats. It was obvious from Table (5) that sodium arsenite -treated rats group has MDA levels that were substantially increased $(p<0.05)$, and their GPx, SOD and CAT levels were significantly reduced $(p<0.05)$. Results of GPx, SOD and CAT showed that all treated groups recorded high significant increase when compared with the positive control group. On the other hand, all treated groups recorded significant decrease in MDA when compared with the positive control group. 


\section{Potential ameliorative effects of Ocimum basilicum extract and leaves on testicular toxicity induced by sodium arsenite in male rats}

Table (5): Effect of Ocimum basilicum extract and leaves on antioxidant enzymes and malondialdehyde in rats with induced testicular toxicity.

\begin{tabular}{|c|c|c|c|c|}
\hline \multirow[b]{2}{*}{ Groups } & \multicolumn{4}{|c|}{ Parameters } \\
\hline & $\begin{array}{c}\text { GPX (ng/mg } \\
\text { protein) }\end{array}$ & $\begin{array}{c}\text { SOD } \\
\text { (U/min/mg } \\
\text { protein) }\end{array}$ & $\begin{array}{c}\text { CAT } \\
\text { (U/min/mg } \\
\text { protein) }\end{array}$ & $\begin{array}{c}\text { MDA } \\
\text { (nmol/mg } \\
\text { protein) }\end{array}$ \\
\hline Control-ve & $0.45 \pm 0.02^{\mathrm{a}}$ & $0.35 \pm 0.02^{\mathrm{a}}$ & $0.33 \pm 0.01^{\mathrm{a}}$ & $0.13 \pm 0.01^{\mathrm{e}}$ \\
\hline Control +ve & $0.19 \pm 0.02^{\mathrm{e}}$ & $0.13 \pm 0.02^{\mathrm{e}}$ & $0.15 \pm 0.02^{\mathrm{e}}$ & $0.32 \pm 0.01^{\mathrm{a}}$ \\
\hline Ocimum extract $(250 \mathrm{mg} / \mathrm{kg})$ & $0.32 \pm 0.01^{\mathrm{c}}$ & $0.27 \pm 0.008^{\mathrm{cd}}$ & $0.26 \pm 0.01^{\mathrm{c}}$ & $0.20 \pm 0.02^{\mathrm{bc}}$ \\
\hline Ocimum extract $(500 \mathrm{mg} / \mathrm{kg})$ & $0.37 \pm 0.01^{b}$ & $0.33 \pm 0.01^{\mathrm{ab}}$ & $0.30 \pm 0.01^{\mathrm{b}}$ & $0.16 \pm 0.02^{\mathrm{d}}$ \\
\hline Ocimum powder equalize extract $(250 \mathrm{mg} / \mathrm{kg})$ & $0.27 \pm 0.02^{\mathrm{d}}$ & $0.26 \pm 0.02^{\mathrm{d}}$ & $0.22 \pm 0.01^{\mathrm{d}}$ & $0.22 \pm 0.02^{\mathrm{b}}$ \\
\hline Ocimum powder equalize extract $(500 \mathrm{mg} / \mathrm{kg})$ & $0.31 \pm 0.02^{\mathrm{c}}$ & $0.30 \pm 0.02^{\mathrm{bc}}$ & $0.25 \pm 0.01^{\mathrm{c}}$ & $0.17 \pm 0.02^{\mathrm{cd}}$ \\
\hline
\end{tabular}

Data are presented as mean \pm SD. Values with different letters indicate significant differences among groups at $\mathrm{p} \leq 0.05$.

\section{DISCUSSION}

The role of nutritional and biochemical factors in reproduction and sub fertility treatment is very important. Oxidants and antioxidants have attracted widespread interest in nutrition research, biology and medicine. Several conditions can interfere with spermatogenesis and reduce sperm quality and production. Earlier studies have shown that exposure to arsenic caused male reproductive toxicity when administered by means of drinking water (Souza et al., 2016; Momeni and Eskandari, 2012). Male germ cells may be susceptible to oxidative stress because of high concentration of polyunsaturated fatty acids and low antioxidant capacity. It may also reduce the epididymal sperm count, viability, motility and the activity of antioxidant defense system (Momeni and Najmeh, 2012).

In the present investigation feed intake, body weight gain, feed efficiency ratio and organ-body weight were decreased in rats with testicular toxicity and this was in accordance with the result of Muthumani and Miltonprabu (2012) on rats. The significant decrease of body weight in arsenic rats group was in agreement with previous findings of Sharma et al. (2007).

In the current study the decrease in sperm count, sperm motility and form may be related to the fact that arsenic exposure causes increased production of free radicals, thus affecting the sperm production in the testes and its retention in seminiferous tubules (Kumar et al., 2015; Adedara et al., 2017).Sharma and Kumar (2011) mentioned that arsenic exerts its toxicity by generating reactive oxygen species (ROS) during redox cycling and metabolic activation processes that causes tissue damages. Free radicals damage biomembrane, reflected by increased lipid peroxidation oxidation of nucleic acid and protein, thereby compromising cellular integrity and function. Compounds containing arsenic were reported to cause DNA damage by reactions involving free radicals resulting in defective sperms (Momeni and Eskandari, 2012). On the other hand, Guvvala et al. (2016) found that the seminiferous tubules' diameter and the sperm quality were suppressed by arsenic. Significant decrease in sperm counts was also observed in arsenic exposed rats in the present study. Arsenic is a well-known thiolinhibiting metalloid necessary to maintain sperm mortality and stability. The decrease in sperm motility in the present study may be due to accumulation of arsenic in the epididymis where the sperm matures and acquires motility and due to low availability of testosterone in arsenic treated rats 
Lamiaa M. Abd EL-Maoula

(Muthumani and Miltonprabu, 2012; Ali et al., 2013).

Also, the current results showed that sodium arsenite induced significant decrease in testes hermon's (FSH, LH and testesteron), GPX, SOD and CAT. A significant decrease in the weights of testis and accessory sex organs was observed in arsenic exposed rats, which may be due to the inhibition of spermatogenesis and decreased steroidogenesis. Arsenic has been found to have an inhibitory effect on the activity of testicular steroidogenic and reduces the weight of the testes, accessory sex glands in rats and suppress the sensitivity of gonadotroph cells to $\mathrm{GnRH}$ (Gonodotropin releasing hormone) (Ali et al., 2013). It is well known that the testosterone stimulates normal growth and function of male reproductive system (Dohle et al., 2003). The weight of the testis is also largely dependent on the mass of the differentiated spermatogenic cells and reduction in the testicular weight indicates germ cell loss (Sarkar et al., 2003). Mukhopadhyay et al. (2013) had observed a decrease in serum testosterone levels along with significant diminution in testicular glutathione S-transferase activity and reduced glutathione level. Samir et al. (2016) mentioned that Arsenic decreases the levels of testicular superoxide dismutase (SOD), catalase (CAT), reduced glutathione, and zinc. Moreover, arsenic significantly decreased plasma testosterone, luteinizing hormone $(\mathrm{LH})$, sperm motility and sperm count. Arsenic also reduces the levels of follicle-stimulatinghormone $(\mathrm{FSH})$ and luteinizing hormone ( $\mathrm{LH})$, leading to decreased testosterone production. Arsenic has a high affinity for sulfhydryl-containing glutathione. Binding of arsenic with sulfhydryl groups of glutathione (Flora et al.,2007) leads to the depletion of glutathione (Lawley et al., 2014; Reddy et al., 2011) resulting in inhibition of glutathione reductase, thus producing excessive reactive oxygen species in the testis. Increased production of free radicals leads to lipid peroxidation in the cell membranes and finally damage to the cell. Increased free radical production interferes with the functioning of the antioxidant defense system, and this result in tissue injury (Díaz-Villaseñor et al., 2007). In the current study arsenic (AS) led to a significant increase in testicular malondialdehyde (MDA) which in agreement with the observation of Manna et al. (2008).

The results of the present work indicated that administration of $O$. basilicum leaves and extract protects the testis from sodium arsenite toxicity as indicated by increase in sperm count, sperm motility, Progressive motility, Normal form, testes hermon's (FSH, LH and testesteron), prostate weight, tests weight, weight gain , SOD, CAT and also showed significant decrease in MDA compared with sodium arsenite rats. In accordance with these results, Khaki et al. (2011a) reported that $O$. basilicum extract protected rats from testicular damage and reduced apoptosis after exposure to an electromagnetic field. Asuquo et al. (2010) found that $O$. gratissimum extract improved the testicular histopathological alterations in diabetic rats. The present study showed an increase in the body weight of treated rats with $O$. basilicum leaves and extract which in agreement with Bayomy et al. (2016) who found that administration of Ocimum basilicum and adriamycin (ADR) caused significant increase in body weight of rats.

The present study confirmed that $O$. basilicum had beneficial effects on male reproductive activity and testes hermon's. Male rats received $O$. basilicum extract showed significantly increased in total testosterone serum, sperm concentration, percentage of sperm viability and sperm 


\section{Potential ameliorative effects of Ocimum basilicum extract and leaves on testicular toxicity induced by sodium arsenite in male rats}

motility which support the results of Khaki et al, (2011b) who mentioned that $O$. basilicum extract may be a promising treatment for enhancing healthy sperm parameters. On the other hand, Umar et al. (2012) found that leaves of O. basilicum have increased sperm motility, viability, sperm count, and total antioxidant capacity but decrease malondialdehyde in HFDinduced obese mice. Moreover, Mohammed (2016) found that the extract of $O$. basilicum dry leaves enhanced the serum FSH and LH levels and increased fertility in rabbit.

The current findings reported that $O$. basilicum had beneficial effects on antioxidant activities and maintenance of antioxidant enzymes. The leaves of $O$. basilicum are a rich source of flavonoids which possess various biological properties related to antioxidant mechanisms (Zhang et al., 2009). Polyphenolic compounds are most abundant natural antioxidants and their radical scavenging capabilities play an important role in preventing many chronic diseases (Garcia-Lafuente et al., 2009; Rathee et al., 2009). The antioxidant activity of the plant may be due to flavonoids which have shown to possess various biological properties related to antioxidant mechanism (Marzouk, 2009). Caffeic acid is another component in the leaf of the $O$. basilicum that has antioxidant, antiinflammatory, and cancer chemopreventive activities (Neradil et al., 2003). Another constituent of $O$. basilicum is A p-coumaric acid possess radical scavenging and antioxidant activity at high concentration (Yeh and Yen, 2003). Recent studies reported that the antioxidant activity of Basil (Ocimum basilicum leaves) could be attributed to its bioactive phenolic compounds in leaves and flowers (Prinsi et al., 2020). In addition, other researchers (Noor et al., 2019; Eftekha et al., 2019) reported that $O$. basilicum has high antioxidant activity against oxidative stress. It also has immunomodulatory, antinflammatory, antiapoptotic and cell regeneration effects (Ibrahim et al., 2020).

The protective effect of $O$. basilicum extract on doxorubicin/irradiation-induced testicular injury was studied in rats; the extract elevated testicular total antioxidant capacity, nuclear erythroid-related factor-2 and testosterone contents. These changes were also accompanied by restoration of testicular architecture (Ibrahim et al., 2020).

Mohan et al. (2011) found that the aqueous extracts of various parts of $O$. basilicum increased antioxidant enzymes such as superoxide dismutase (SOD), catalase (CAT), glutathione peroxidase $\left(\mathrm{GP}_{\mathrm{X}}\right)$ and glutathione transferase (GT). These findings in line with El-Nahal et al. (2012) reported that sweet basil (Ocimum basilicum) leaves extract may play a role in improving the activity of antioxidant enzymes and decrease the lipid peroxidation (malondialdehyde, (MDA) and level of $\mathrm{H}_{2} \mathrm{O}_{2}$ in serum.

\section{CONCLUSIONS}

The beneficial actions of Ocimum basilicum against arsenic are believed to originate from its free radical scavenging, antioxidant activities, maintenance of antioxidant enzymes, and a decrease in the production of inflammatory mediators that are implicated in the pathogenesis of arsenic-induced testicular injury. Therefore, Ocimum basilicum represents a potential agent to prevent testicular injury and dysfunction induced by arsenic exposure.

\section{REFERENCES}

Adedara, I.A.; Abolaji, A.O.; Awogbindin, I.O. and Farombi, E.O. (2017). Suppression of the brain-pituitarytesticular axis functions following acute arsenic and manganese co- 
Lamiaa M. Abd EL-Maoula

exposure and withdrawal in rats. $\mathrm{J}$ Trace Elem. Med. Biol. ; 39: 21-29.

Aebi, H. (1984). Methods enzymol. Copyright (C) 1984 Published by Elsevier Inc, 105: 121-126.

Ahmed, M.; Batool, S.; Sharif, A.; Akram, M. and Saeed, M. (2015). Biological and Pharmacological Properties of the Sweet Basil (Ocimum basilicum). J. Pharmaceu. Res. Int., 7: 330-339.

Ali, M.; Shabbir, A.K.; Pushplata, D.; Nath, A.; Singh, J.K.; Kumar, R. and Kumar, A. (2013). Impact of arsenic on testosterone synthesis pathway and sperm production in mice. Innovative J. Med. Health Sci., 3: $185-189$.

Asuquo, O.R.; Edet, A.G.; Mesembe, O. and Atanghwo, J.I. (2010). Ethanolic extracts of Vernonia amygdalina and Ocimum

gratissimum enhance testicular improvement in diabetic Wistar rats. Int. J. Altern. Med., 8: 1-6.

Batra, M. and Gupta, R.P. (2006). Effects of Ocimum sanctum leaf on pathology and immune response in chickens experimentally infected with hydropericardium syndrome. Ind. J. Vet. Pathol., 30:14.

Bayomy, M. F. F.; Sakr, S. A and Gendia, S. E. M. (2016). Biochemical and histological studies on the possible protective impact of the herb basil (Ocimum basilicum) on adriamycin induced toxicity in rats. I. Influence on the liver. J. Biosci. Appl. Res., 2 (9): 634-640.

Chapman, D.G.; Gastilla, R. and Campbell, T.A. (1959). Evaluation of protein in food. I. A. Method for the determination of protein efficiency ratio. Can. J. Biochem. Physio., 1(37): 679-686.
Da Silva, R.F.; Borges, C.D.S.; de Almeida, L.C.; Cagnon, V.H.A.; de Grava and Kempinas, W. (2017). Arsenic trioxide exposure impairs testicular morphology in adult male mice and consequent fetus viability. J. Toxicol. Environ. Health A., 80 (19-21): 1166-1179.

Das, J.; Jyotirmoy, G.; Prasenjit, M.; Mahua, S. and Sil, P.C. (2009). Taurine protects rat testes against $\mathrm{NaAsO}_{2-}$ induced oxidative stress and apoptosis via mitochondrial dependent and independent pathways. Toxicology Letters, 187: 201-210.

Díaz-Villaseñor, A.; Burns, A.L.; Hiriart, M.; Cebrián, M.E. and OstroskyWegman, P. (2007). Arsenic-induced alteration in the expression of genes related to type 2 diabetes mellitus. Toxicol. Appl. Pharmacol., 225 (2): 123-133.

Dohle, G. R.; Smit, M. and Weber, R. F. A. (2003). Androgens and male fertility. World J. Urology, 21(5): 341-345.

Eftekhar, N.; Moghimi, A.; Mohammadian, R.N.; Saadat, S. and Boskabady, M.H. (2019). Immunomodulatory and anti-inflammatory effects of hydro-ethanolic extract of Ocimum basilicum leaves and its effect on lung pathological changes in an ova lbumin-induced rat model of asthma. BMC Complement. Altern. Med., 19(1): 349.

Ekaluo, U.B.; Udokpoh, A.E.; Udofia, U.U. and Ajang, R.O. (2005). Comparative toxicity of five commonly used analgesics on sperm count and sperm head abnormalities. Glob. J. Pure Appl. Sci.,11: 81-84.

Ekaluo, U.B.E.V.; Ikpeme, Y.B. and Ibiang, O.S. (2013). Amaechina, Attenuating role of vitamin $\mathrm{C}$ on sperm toxicity 


\section{Potential ameliorative effects of Ocimum basilicum extract and leaves on testicular toxicity induced by sodium arsenite in male rats}

induced by monosodium glutamate in albino rats. J. Biol. Sci., 13: 298-301.

El-Nahal, D.M.; Thabet, H.A. and Ahmed, S.E.F. (2012). Study the impact of sweet basil extracts (Ocimum basilicum) to reduce blood cholesterol. Egypt. J. Nutr. Health, 7 (1): 51-68.

Flora, S.J.; Bhadauria, S.; Kannan, G.M. and Singh N. (2007). Arsenic induced oxidative stress and the role of antioxidant supplementation during chelation: A review. J Environ Biol. 28 (2): 333 -347.

Garcia-Lafuente, A.; Guillamon, E.; Villares, A.; Rostagno, M.A. and Martinez, J.A. (2009). Flavonoids as anti-inflammatory agents: implications in cancer and cardiovascular disease. Inflamm. Res., 58: 537-552.

Goupy, P.; Hugues, M.; Biovin, P. and Amiot, M. (1999). Antioxidant composition and activity of barley (Hordeum vulgare) and malt extracts of isolated phenolic compounds. J.Sci. Food Agric., 79:1625-1634.

Guvvala, P.R.; Sellappan, S. and Parameswaraiah, R.J. (2016). Impact of arsenic (V) on testicular oxidative stress and sperm functional attributes in Swiss albino mice. Environ. Sci. Pollut. Res. Int., 23(18): 1820018210.

Harnafi, H.; Aziz, M. and Amrani, S. (2009). Sweet basil (Ocimum basilicum L.) improves lipid metabolism in hypercholesterolemic rats. E Spen Eur E J. Clin. Nutr. Metab.,4:181-186.

Ibrahim, R.Y.M.; Mansour, S.M. and Elkady, W.M. (2020). Phytochemical profile and protective effect of Ocimum basilicum aqueous extract in doxorubicin/ irradiation- induced testicular injury. J Pharm. Pharmacol., 72(1):101-110.

Khaki, A.; Fathiazad, F.; Nouri, M. and Khaki, A.A. (2011a). Effect of Ocimum basilicum on apoptosis in testis of rats after exposure to electromagnetic field. Afr. J. Pharm. Pharmacol., 5:1534-1537.

Khaki, A.; Fathiazad, F.; Nouri, M.; Khaki, A.A. (2011b). Effects of basil, Ocimum basilicum on spermatogenesis in rats. J. Med. Plants Res., 5(18):4601-4604.

Kumar, A.; Kumar, R. and Rahman, M.S. (2015). Phytoremedial effect of Withania somnifera against arsenic induced testicular toxicity in Charles Foster rats. Avicenna J. Phytomed.,5 (4): 355-364.

Lawley, S.D.; Yun, J; Gamble, M.V.; Hall, M.N.; Reed, M.C. and Nijhout, H.F. (2014). Mathematical modeling of the effects of glutathione on arsenic methylation. Theor. Biol. Med. Model., 16: 11-20.

Mamoun, M.A.; Qazi, S.M. and Alamgir I. (2018). Reduction of body and testicular weight of albino rats in arsenic toxicity. Ann, Punjab Med. Coll., 12: 3.

Manna, P.; Sinha, M. and Sil, P.C. (2008). Protection of arsenic-induced testicular oxidative stress by arjunolic acid. Redox Rep., 13(2): 67-77.

Manosroi, J.; Dhumtanom, P. and Manosroi, A. (2006). Anti-proliferative activity of essential oil extracted from Thai medicinal plants on $\mathrm{KB}$ and P388 cell lines. Cancer Lett.,235:114-120

Marzouk, A.M. (2009). Hepatoprotective Triterpenes from Hairy Root Cultures of Ocimum basilicum L. Z. Naturforsch. 64 c: $201-$ 209. https://doi.org/10.1515/znc2009-3-409. 
Lamiaa M. Abd EL-Maoula

Mehranjani, M.S. and Hemadi, M. (2007). The effects of sodium a rsenite on the testis structure and sex hormones in vasectomised rats. Iran. J. Reprod. Med., 5: 127-133.

Mohammed, F.S. (2016). Treatment trends on basil herb: The hypothesis of increasing rabbit's male sexual hormones (FSH and $\mathrm{LH}$ ) and related fertility. 8th Annual Pharma Middle East Congress, 10-12, Dubai, UAE.

Mohan, L.; Amberkar, M.V. and Kumari, M. (2011). Ocimum santum L. (Tulsi) An Overview - A Review Article. Int. J. Pharmaceu. Sci. -Review and Research. 7: 51-3.

Momeni, H.R. and Eskandari, N. (2012). Effect of vitamin $E$ on sperm parameters and DNA integrity in sodium arsenite-treated rats. Iran J. Reprod. 10 (3): 249-256.

Mukhopadhyay, P.K.; Dey, A.; Mukherjee, S. and Pradhan NK. (2013). The effect of coadministration of $\alpha$ tocopherol and ascorbic acid on arsenic trioxide- induced testicular toxicity in adult rats. J. Basic Clin. Physiol. Pharmacol., 24 (4):245-253.

Muthumani, M. and Miltonprabu, S. (2012). Silibinin ameliorates oxidative stress mediated testicular damage by arsenic in rats. Asian Pacific J. Tropical Biomed., 1:1 -7.

Neradil, J.; Veselská, R. and Slanina, J. (2003). UVC-protective effect of caffeic acid on normal and transformed human skin cells in vitro. Folia Biol (Praha), 49:197202.

Nishikimi, M.; Roa, N.a. and Yogi,K. (1972). Biochem. Bioph. Res. Common., 46:849-854.
Noor, Z.I.; Ahmed, D.; Rehman, H.M.; Qamar, M.T.; Froeyen, M.; hmad S. and Mirza, M.U. (2019). In Vitro antidiabetic, anti-obesity and antioxidant analysis of Ocimum basilicum aerial biomass and in silico molecular docking simulations with alpha-amylase and lipase enzymes. Biology, 8(4): 92.

Ohkawa, H.; Ohishi, W. and yagi, k. (1979). Assay for lipid peroxides in animal tissues by thiobarbituric acid reaction. Anal. Biochem. 95 (2):351358.

Ommati, M.M.; Heidari, R.; Manthari, R.K.; Tikka, S.C.J.; Niu, R. and Sun, Z. (2019). Paternal exposure to arsenic resulted in oxidative stress, autophagy, and mitochondrial impairments in the HPG axis of pubertal male offspring. Chemosphere, 236: 124325.

Paglia, D.E. and Valentine,W. J. (1967). Studies on the quantitative and qualitative characterization of erythrocyte glutathione peroxidase. Lab.Clin. Med., 70 (1):158-169.

Preethi, C.; Laxminarayana, K. B. and Archana, P. R. (2020). Effect of aqueous seed extract of Mucuna pruriens on arsenic-induced testicular toxicity in mice. Asian Pacific J. Reprod., 9(2):77-82.

Prinsi, B.; Morgutti, S.; Negrini, N.; Faoro, F. and Espen, L. (2020). Insight into composition of bioactive phenolic compounds in leaves and flowers of green and purple basil. Plants. 9(1): 22-37.

Rathee, P.; Chaudhary, H.; Rathee, S.; Rathee, D.; Kumar, V. and Kohli, K. (2009). Mechanism of action of flavonoids as anti-inflammatory agents: a review. Inflamm. Allergy Drug. Targets. 8: 229-235. 


\section{Potential ameliorative effects of Ocimum basilicum extract and leaves on testicular toxicity induced by sodium arsenite in male rats}

Reddy, P.S.; Rani, G.P.; Sainath, S.B.; Meena, R. and Supriya, C.H. (2011). Protective effects of $\mathrm{N}$-acetylcysteine against arsenic induced oxidative stress and reprotoxicity in male mice. J. Trace Elem. Med. Biol., 25 (4): 247-253.

Samir, A.E.; Bashandy, S.A.; El Awdan, H.E. and Ibrahim, M.A. (2016). Antioxidant Potential of Spirulina platensis Mitigates Oxidative Stress and Reprotoxicity Induced by Sodium Arsenite in Male Rats. Oxidative Medicine and Cellular Longevity Volume 2016, 1-8.

Sarkar, M.; Chaudhuri, $\quad$ G. $\quad$ R.; Chattopadhyay, A. and Biswas, N. M. (2003). Effect of sodium arsenite on spermatogenesis, plasma gonadotrophins and testosterone in rats. Asian J. Andrology, 5(1):27-31.

Sendcor, G. and Cochran, W. (1979). Statistical Method 6th ed. Lowa State Collage U. S. A., 841.

Sethi, J.; Sood, S.; Seth, S. and Talwar, A. (2003). Protective effect of Tulsi (Ocimum sanctum) on lipid peroxidation in stress induced by anemic hypoxia in rabbits. Ind. J. Physiol. Pharmacol., 47:115-119.

Sharma, G. and Kumar, M. (2011). Morphometrical study of sem iniferous tubules of mice after using arsenic and Chlorophytum borivilianum. Pharmacology online 2: 348 -359.

Sharma, A.; Kumar,M. and Sharma, M. K. (2007). Protective effect of Mentha piperita against arsenic-induced toxicity in liver of swiss albino mice. J. Compilation Nordic Pharmacological Society. Basic Clin. Pharmacol. Toxicol., 100(4): 249-257.

Souza. A.C.; Marchesi, S.C.; Ferraz, R.P.; Lima, G.D.; de Oliveira, J.A. and Machado- Neves, M. (2016). Effects of sodium arsenate and arsenite on male reproductive functions in Wistar rats. J. Toxicol. Environ. Health, 79 (6): 274-286.

Tietz, N.W. (1995). Clinical guide to laboratory tests. 3rd ed Philadelphia:W.B. Saunders, Co. p.405.

Umar, I.; Mohammed, A.; Dawud, F.; Kabir, A.; Sai, J.; Muhammad, F. and Okalor M. (2012). The hypolipidemic and antioxidant actions of aqueous extracts of Ocimum basilicum and Ocimum suave in high fat fed Rats. J. Med. Plants Res., 6:3501-5.

Uotila, M., Ruoslathi, E., and Envall E. (1981). Two-site sandwich enzyme immunoassay with monoclonal antibodies to human alphafetoprotein. $\mathbf{J}$. Immunol. Methods, 42:11-15.

Villaseñor, I.M.; Echegoyen, D.E. and Angelada, J.S. (2002). A new antimutagen from Mentha cordifolia Opiz. Mutat. Res.J., 515: 141-146.

Yeh. C.T. and Yen, G.C. (2003). Effects of phenolic acids on human phenolsulfotransferases in relation to their antioxidant activity. J Agric Food Chem., 51:1474-1479.

Zhang, F.; Lau, S.S. and Monks, T.J. (2011). The cytoprotective effect of $\mathrm{N}$ acetyl-L- cysteine against ROSinduced cytotoxicity is independent of its ability to enhance glutathione synthesis. Toxicol Sci., 120 (1): 87-97.

Zhang, J.W.; Li, S.K. and Wu, W.J. (2009). The main chemical composition and in vitro antifungal activity of the essential oils of Ocimum basilicum Linn. var. pilosum (Willd.) Benth. Molecules. 14:273-278.

Zubair, M.; Ahmad, M. and Qureshi, Z.I. (2017). Review on arsenic-induced toxicity in male reproductive system and its amelioration. Andrologia, 49(9): 12791. 


\section{Lamiaa M. Abd EL-Maoula}

التأثيرات التحسينية المحتملة لمستخلص الريحان وأوراقه على سمية الخصية المحدثة بزرنيخ الصوديوم في ذكور الجرذان لمياء مصطفى عبد المولى الإنى

قسم التغذِية و علوم الأطعمة ، كلّية الاقتصاد مصطى المنزلَّى ، جامعة الأز هر ،طنطا، مصر

$$
\begin{aligned}
& \text { المستخلص } \\
& \text { يعرف الزرنيخ بانه مادة كيميائية بيئية ذات تأثنير انجابى سام وذللك من خلال تثيط تكوين الحيوانات المنوية }
\end{aligned}
$$

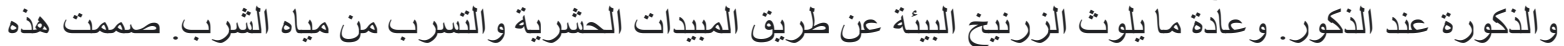

